\title{
Hydrocarbons in surface sediments of harbor areas in a tropical region (Ceará state, northeast Brazil)
}

\author{
Lucas Moreira Buruaem ${ }^{1} \cdot$ Satie Taniguchi $^{2} \cdot$ Silvio Tarou Sasaki ${ }^{2} \cdot$ \\ Márcia Caruso Bícego $^{2} \cdot$ Leticia Veras Costa-Lotufo $^{3} \cdot$ Denis Moledo Souza Abessa $^{1}$
}

Received: 28 August 2015/ Accepted: 12 February 2016/Published online: 11 April 2016

(C) Springer-Verlag Berlin Heidelberg 2016

\begin{abstract}
Sediment samples collected in two harbors of a tropical region of Brazil were investigated for the distribution of linear alkylbenzenes (LABs), aliphatic (AHs) and polycyclic aromatic hydrocarbons (PAHs). The levels of hydrocarbons in sediments from Mucuripe and Pecém harbors were lower than those reported in industrialized sites and threshold levels of sediment quality guidelines. Analysis of AHs revealed an input of biogenic compounds and, according to diagnostic ratios, PAHs in both harbors originated from pyrogenic sources, which can be related to harbor activities. The contribution of local and diffuse sources seemed to be less important, but not negligible. Deposition zones in both harbors are associated to sedimentation of particles, biogenic materials and hydrocarbons. The results of this study can assist in characterization and management of dredged material by providing information on the distribution and sources of hydrocarbons along the tropical zones, which is important for the identification of ecological risks associated with these compounds.
\end{abstract}

Electronic supplementary material The online version of this article (doi:10.1007/s12665-016-5453-4) contains supplementary material, which is available to authorized users.

Lucas Moreira Buruaem

lburuaem@gmail.com

1 Núcleo de Estudos em Poluição e Ecotoxicologia Aquática (NEPEA), Universidade Estadual Paulista (UNESP), Pça. Infante D. Henrique s/n ${ }^{\circ}$ São Vicente, SP CEP: 11330-900, Brazil

2 Universidade de São Paulo, Pça. do Oceanográfico, 191, Butantã, SP CEP: 05508120, Brazil

3 Universidade Federal do Ceará, Av. da Abolição, 3207, Meireles, Fortaleza CEP: 60165-081, Brazil
Keywords Dredging - Marine pollution - Sediment contamination · Tropical environments

\section{Introduction}

Harbor activities have important roles in global economy. However, such activities are generally recognized as harmful to coastal environments. Negative impacts related to port installation and operation involve changes in sediment transport due the construction of jetties, dredging and removal of sediments, and increasing contamination due to generation of wastes and discharge of chemicals, such as petroleum and its derivatives (NRC, National Research Council 1997). These activities are often associated with marine pollution and the input of contaminants along the different environmental compartments. In this context, sediments constitute a sink and a secondary source of many compounds, presenting higher concentrations when compared to the water column (Burton 2002).

Port areas may receive loads of petroleum and derivatives and the distribution of these substances in the sediment can be assessed by aliphatic (AHs) and polycyclic aromatic hydrocarbons (PAHs) analysis. AHs are important petroleum derivatives and may also be biosynthesized by marine or terrigenous organisms (Volkman et al. 1992). PAH are released from natural sources such as biomass combustion, volcanic eruptions and diagenesis, while anthropogenic sources include coal and wood burning, oil combustion, industrial activities, effluents and accidental fuel spills (USEPA United States Environmental Protection Agency 2003). Linear alkylbenzenes (LABs) are hydrocarbons that have been released into the environment since the early 1960s as by-products of linear alkylbenzene sulfonate (LAS) detergents, which represents the most widely 
used anionic surfactants in the world. Their environmental occurrence has been related to sewage discharges and source of domestic and industrial wastes (Eganhouse 1986).

To deal with the problem of sediment contamination, different countries, such as much of the European Community, United States and Canada, have developed enforcements and criteria towards the characterization and classification of contaminated sediments (Burton 2002). In Brazil, nevertheless, some efforts have been employed into the development of regulations for marine and estuarine sediments. The Federal Resolution CONAMA 454/12 (Brasil 2012) was published with the purpose of establishing Sediment Quality Guidelines (SQGs) for dredging activities, however, such parameters were based on international values.

Some authors have demonstrated that the use of these SQGs may be ineffective to protect biota from tropical and subtropical areas and recommended the development of site specific values (Choueri et al. 2009; Buruaem et al. 2012). The achievement of this goal requires efforts to expand information on distribution and levels of contaminants in sediments from various sectors of the Brazilian coast, since different coastal areas present distinct climate and sedimentology in a continental-scale, as pointed by Lacerda and Marins (2005). These authors reported a dominance of clastic materials and fines particles in sediments from subtropical areas like in the southeast in relation to the Tropical ones as in the northeast, which is richer in calcium carbonates and sandy sediments.

Mucuripe and Pecém are the two main harbors of Ceara state, located on the northeast region of the Brazilian coast. These ports account for shipping most goods that are produced and traded in this Brazilian region. Thus, these areas are vulnerable to emissions of contaminants typical of harbor areas. Mucuripe is located within Mucuripe bay, in Fortaleza city, state capital of Ceará, and its area comprises the access channel, anchorage areas and evolution basins, which are protected by a long jetty $(1900 \mathrm{~m})$. On the other hand, Pecém port terminal is located in the municipal district of São Gonçalo do Amarante, about $50 \mathrm{~km}$ west from the capital, and is an "offshore" terminal assembled $2000 \mathrm{~m}$ from shoreline.

Fortaleza is one of the most important cities in Brazil, with over 2.3 million in habitants distributed across an area of $313 \mathrm{~km}^{2}$ in its metropolitan region. Different anthropogenic contamination sources are situated along the coastline, such as vehicular emissions (e.g., deposition of particles and gases), harbor areas, drainage from urban pluvial water system (urban runoff) and industrial wastewater, transport and refinement of oil, and sewage discharges (Cavalcante et al. 2009; Cavalcante et al. 2010). Considering the lack of data on the contamination of marine sediments, especially considering tropical regions, the present study aims to determine the composition, levels and sources of hydrocarbons in superficial sediments from the vicinities of Mucuripe and Pecem harbors through the analysis of LABs, AHs and PAHs, once these areas are affected by the potential sources of such compounds.

\section{Materials and methods}

\section{Sediment sampling and handling}

In Mucuripe harbor, sediment sampling was carried out in August 2007 and comprised 10 stations (Fig. 1): M1 and M2 were located at the commercial docks; M3 to M5 were close to tanker piers; M6 and M7 were situated at the access channel; and M8 to M10 were positioned in unsheltered areas. In Pecém terminal port, the collection was carried out in January 2008 and covered five stations (Fig. 1): P1 and P2 were close to the docking piers; P3 and P4 were at the access channel; and P5 was in an unsheltered area. Samples were collected using a Van Veen grab and only the top $2 \mathrm{~cm}$ of surface sediment were sampled. An aliquot was air-dried (Loring and Rantala 1992) and packed in plastic containers for analysis of sediment characteristic, and a second aliquot was stored in aluminum boxes at $-20{ }^{\circ} \mathrm{C}$ for subsequent analysis of hydrocarbons.

\section{Sediment analysis}

Grain size distribution was measured by the wet sieving method (Mudroch and MacKnight 1994). Calcium carbonate contents $\left(\mathrm{CaCO}_{3}\right)$ estimation was conducted by $\mathrm{HCl}$ digestion and gravimetry (Gross 1971). Decarbonated sediments were separated for total organic carbon analysis (TOC), determined on a TOC analyzer model SHIMADZU TOC-V series coupled with SSM-5000A and organic matter content analysis (OM), determined by the method of ignition and gravimetry (Luczak et al. 1997).

The sediment samples were freeze-dried and homogenized. An amount of $20 \mathrm{~g}$ was Soxhlet-extracted with a $50 \%$ mixture of $n$-hexane and dichloromethane for $8 \mathrm{~h}$ according to UNEP (UNEP United Nations Environment Programme 1992). Before extraction, $n$-hexadecene (for AHs), $\mathrm{d}_{8}$-naphthalene, $\mathrm{d}_{10}$-acenaphthene, $\mathrm{d}_{10}$-phenanthrene, $\mathrm{d}_{12}$-chrysene, $\mathrm{d}_{12}$-perylene (for PAHs), and dodecyl 1-benzene $\left(1 \mathrm{C}_{12}\right.$-LAB for LABs) were added as surrogates to all the samples, blanks and reference material. The hydrocarbon extracts were fractionated into $\mathrm{F} 1$ (AHs hydrocarbons and LABs) and F2 (PAHs) by silica gelalumina column chromatography. Twenty-six AHs hydrocarbons ( $n-\mathrm{C}_{17}$ to $n-\mathrm{C}_{35}$, including pristaneand phytane) 


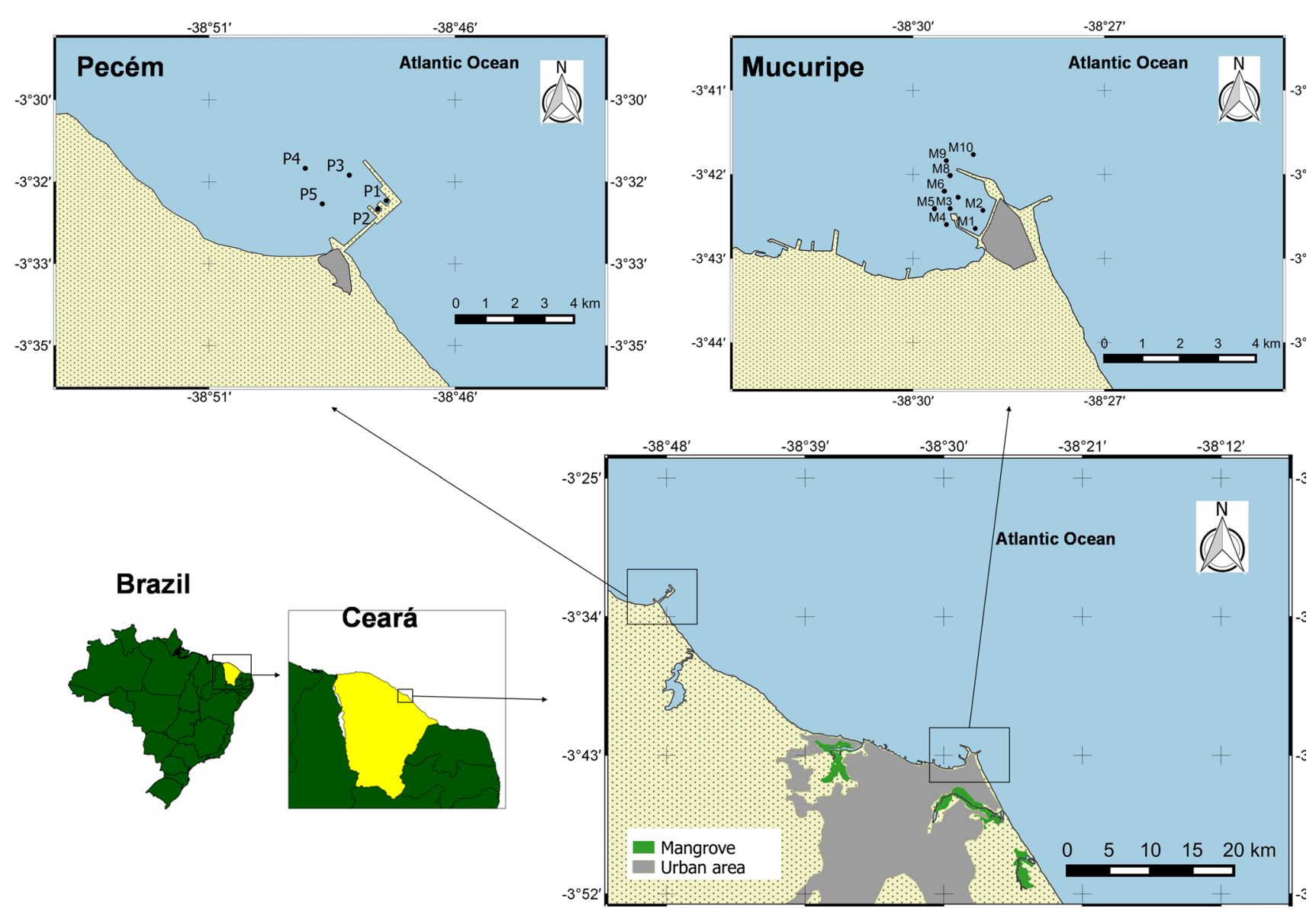

Fig. 1 Sites of sediment sampling in Mucuripe and Pecém harbors

were determined on a gas chromatography 6890 from Agilent Technologies with flame ionization detector (GCFID). Thirty-three PAHs and thirty LABs were quantitatively analysed by an Agilent 6890 gas chromatograph coupled to a $5973 \mathrm{~N}$ mass spectrometer (GC/MS) in a selected ion mode (SIM). The results from all the compounds analyzed are presented in the Supplementary data (Appendix A, B and C).

Quality assurance and quality control (QA/QC) were based on the analysis of procedural blank, blank spike, matrix spike, matrix duplicate and standard reference material. The mean recoveries of surrogates and target compounds were within 65 and $102 \%$. The precision ranged from 1.8 to $12 \%$ for AHs, 1.0 to $17 \%$ for LABs and 1.6 and $19 \%$ for PAHs. The method accuracy was ensured by the analyses of standard reference material from International Atomic Energy Agency (IAEA 417). GC/MSand GCFIDdetection limit (DL) was 0.025 ngfor LAB and PAH, and0.13 ng for AH.Method detection limit (MDL) was based on the standard deviation $(3 \times \sigma)$ of seven replicates of a sediment sample containing target compounds at a level of one to five times the expected MDL.

\section{Results and discussion}

Sediment characteristics are shown in Table 1. The sediments from Mucuripe and Pecém are composed mainly of sand, with higher levels of fine particles (mud) occurring in sheltered areas (M1-M7 and P1-P4). This can be associated with the occurrence of depositional areas induced by jetties, given the high hydrodynamics of this region, and the predominance of trade winds in $\mathrm{E}-\mathrm{W}$ determines the constant transport of sediments towards West (Maia et al. 1998). Calcium carbonates, organic matter and TOC also presented higher levels in depositional areas.

According to Freire et al. (2004), sediments of the coast of Ceará are originated from organogenic and terrigenous facies. Organogenic substrates are derived from calcareous algae (Lithothamnium sp and Halimeda sp), contributing inup to $95 \%$ of calcium carbonate deposition, and organic matter contents ranging, from 20 to $40 \%$. Sediments from terrigenous facies are characterized by siliciclastic material and clay. The texture of the outer shelf particles $(40 \mathrm{~m}$ isobath) consists of gravel and those from the inner shelf 
Table 1 Sediment characteristics, total concentrations of LABs, AHs and PAHs including the diagnostic criteria for sediments collected in Mucuripe and Pecém harbors

\begin{tabular}{|c|c|c|c|c|c|c|c|c|c|c|c|c|c|c|c|}
\hline Sites & $\begin{array}{l}\text { Depth } \\
\text { (m) }\end{array}$ & $\begin{array}{l}\text { Mud } \\
(\%)\end{array}$ & $\begin{array}{l}\mathrm{CaCO}_{3} \\
(\%)\end{array}$ & $\begin{array}{l}\mathrm{OM} \\
(\%)\end{array}$ & $\begin{array}{l}\text { TOC } \\
(\%)\end{array}$ & $\begin{array}{l}\text { Total } \\
\text { LABs } \\
(\mathrm{ng} / \mathrm{g})\end{array}$ & $\begin{array}{l}\text { Total } \\
\text { AHs } \\
(\mu \mathrm{g} / \mathrm{g})\end{array}$ & $\begin{array}{l}\text { Total } \\
n \text {-alk } \\
(\mu \mathrm{g} / \mathrm{g})\end{array}$ & $\begin{array}{l}\mathrm{UCM} \\
(\mu \mathrm{g} / \mathrm{g})\end{array}$ & CPI & DP & $\begin{array}{l}\text { LMW- } \\
\text { PAH } \\
(\mathrm{ng} / \mathrm{g})\end{array}$ & $\begin{array}{l}\text { HMW- } \\
\text { PAH } \\
(\mathrm{ng} / \mathrm{g})\end{array}$ & $\begin{array}{l}\text { Total } \\
\text { PAHs } \\
(\mathrm{ng} / \mathrm{g})\end{array}$ & $\begin{array}{l}\text { LMW/ } \\
\text { HMW }\end{array}$ \\
\hline M1 & 7.4 & 24 & 18.4 & 5.6 & 0.9 & $<0.8$ & 25.7 & 0.8 & 22.0 & 2.9 & ${ }^{n-} \mathrm{C}_{30}$ & 18.0 & 59.9 & 77.9 & 0.3 \\
\hline M2 & 15.0 & 7.9 & 30.3 & 12.7 & 1.4 & $<0.8$ & 19.1 & 0.6 & 16.0 & 2.9 & ${ }^{n-} \mathrm{C}_{29}$ & 41.6 & 66.2 & 107.8 & 0.6 \\
\hline M3 & 15.4 & 22.7 & 25.0 & 6.0 & 0.9 & $<0.8$ & 17.6 & 0.9 & 14.8 & 4.9 & ${ }^{n-} \mathrm{C}_{29}$ & 15.7 & 44.0 & 59.7 & 0.4 \\
\hline M4 & 14.7 & 24.4 & 35.0 & 16.2 & 1.4 & 5.8 & 21.1 & 1.3 & 17.2 & 3.8 & ${ }^{n-} \mathrm{C}_{29}$ & 34.0 & 53.9 & 87.9 & 0.6 \\
\hline M5 & 10.7 & 15.6 & 15.7 & 3.3 & 0.4 & $<0.8$ & 1.1 & 0.2 & $\mathrm{NC}$ & 4.5 & ${ }^{n-}$ & 3.5 & 24.4 & 28.0 & 0.1 \\
\hline M6 & 14.6 & 16.7 & 26.6 & 8.6 & 1.1 & 1.3 & 2.5 & 1.1 & $\mathrm{NC}$ & 4.6 & ${ }^{n-}$ & 9.0 & 27.7 & 36.7 & 0.3 \\
\hline M7 & 9.6 & 5.4 & 22.2 & 12.2 & 0.8 & $<0.8$ & 13.5 & 0.7 & 11.1 & 4.6 & ${ }^{n-} \mathrm{C}_{31}$ & 5.9 & 37.5 & 43.4 & 0.2 \\
\hline M8 & 9.6 & 0.6 & 9.4 & 1.0 & 0.2 & $<0.8$ & 1.0 & 0.1 & $\mathrm{NC}$ & $\mathrm{NC}$ & ${ }^{n-} \mathrm{C}_{17}$ & $<1.00$ & $<1.00$ & $<1.0$ & $\mathrm{NC}$ \\
\hline M9 & 11.9 & 0.1 & 5.7 & 0.5 & 0.2 & $<0.8$ & 0.5 & 0.1 & $\mathrm{NC}$ & $\mathrm{NC}$ & ${ }^{n-} \mathrm{C}_{24}$ & $<1.00$ & $<1.00$ & $<1.0$ & $\mathrm{NC}$ \\
\hline M10 & 12.6 & 0.0 & 8.6 & 0.1 & 0.2 & $<0.8$ & 0.3 & 0.1 & $\mathrm{NC}$ & $\mathrm{NC}$ & ${ }^{n-} \mathrm{C}_{17}$ & $<1.00$ & $<1.00$ & $<1.0$ & $\mathrm{NC}$ \\
\hline P1 & 16.7 & 4.4 & 37.0 & 14.9 & 1.3 & 3.2 & 14.8 & 0.7 & 12.6 & 2.1 & ${ }^{n-} \mathrm{C}_{31}$ & 49.4 & 94.5 & 143.9 & 0.5 \\
\hline $\mathrm{P} 2$ & 16.4 & 10.9 & 33.8 & 12.2 & 1.1 & 2.9 & 19.5 & 0.9 & 16.7 & 2.8 & ${ }^{n-} \mathrm{C}_{29}$ & 64.9 & 227.1 & 292.0 & 0.3 \\
\hline P3 & 17.5 & 8.2 & 29.0 & 14.7 & 1.4 & 4 & 17.4 & 1.0 & 14.7 & 1.8 & ${ }^{n-} \mathrm{C}_{31}$ & 25.0 & 52.2 & 77.2 & 0.5 \\
\hline P4 & 17.2 & 14.3 & 26.5 & 7.7 & 0.8 & 1.6 & 1.5 & 0.7 & $\mathrm{NC}$ & 2.5 & ${ }^{n-} \mathrm{C}_{29}$ & 10.2 & 21.8 & 31.9 & 0.5 \\
\hline P5 & 15.1 & 6.9 & 24.8 & 2.5 & 0.5 & $<0.8$ & 1.1 & 0.4 & $\mathrm{NC}$ & 2.6 & $\stackrel{n-}{\mathrm{C}_{29}}$ & 68.3 & 114.6 & 182.9 & 0.6 \\
\hline
\end{tabular}

Total LABs total linear alkylbenzenes, Total $n$-alk total $n$-alkanes, Total AHs total aliphatic hydrocarbons $\left(n-\mathrm{C}_{12}-n\right.$ - $\left.\mathrm{C}_{34}\right)$, $U C M$ unresolved complex mixture, $C P I$ carbon preference index $\left(n-\mathrm{C}_{25}-n-\mathrm{C}_{33}\right), D P$ dominant peaks, $L M W-P A H$ low molecular weight PAHs (sum of 2 and 3 rings PAHs), $H M W-P A H s$ high molecular weight PAHs (sum of 4-6 rings PAHs), $N C$ not calculated

(below the $20 \mathrm{~m}$ isobath) are composed of sand, biodetritic gravels and low amounts of mud (below $2.5 \%$ ).

Total concentrations of LABs are given in Table 1. In both areas only $\mathrm{C}_{13}$-LABs (tridecylbenzene) were detected. Moreover, concentration of $\mathrm{LABs}$ was found to be very low compared with other polluted places (Wei et al. 2014); in the most samples, values were below detection limits. In Mucuripe, LABs were found only in M4 and M6 (1.3 and $5.8 \mathrm{ng} / \mathrm{g}$, respectively), while, in Pecém, they were found in $\mathrm{P} 1-\mathrm{P} 4$, ranging from 1.6 to $4 \mathrm{ng} / \mathrm{g}$. The main source of sewage in Mucuripe harbor can be attributed to discharge of drainage channels of urban pluvial water system, which also receives inputs of illegal sewage. In Pecém, the potential source of sewage is the Oceanic Outfall System that was designed to release industrial and domestic sewage effluents from the harbor facilities. For both harbors, the contribution of such source seems to be small.

According to Raymundo and Preston (1992) compositions of most commercial detergents presented LABs with 11 and 12 carbons atoms in the alkyl chain $\left(\mathrm{C}_{11}\right.$-LABs and $\mathrm{C}_{12}$-LABs) in their formulations. However, the only compounds detected in both harbors were the $\mathrm{C}_{13}$-LABs. The presence of $\mathrm{C}_{13}$-LABs can be explained by their low solubility in water and high affinity for organic matter, which were assessed by octanol-water partition coefficient (Kow) by Sherblom et al. (1992). These values can be considered as baseline for samples collected in harbors and nearby areas.

Total concentrations of the AHs, including $n$-alkanes (from $\mathrm{C}_{12}$ to $\mathrm{C}_{35}$ ), unresolved complex mixture (UCM), carbon preference index (CPI) and dominant peaks are also 
presented in Table 1. The concentrations in samples ranged from 0.3 to $25.7 \mu \mathrm{g} / \mathrm{g}$ in Mucuripe and 1.1 to $19.5 \mu \mathrm{g} / \mathrm{g}$ in Pecém. Total $n$-alkanes concentrations ranged from 0.1 to $1.3 \mu \mathrm{g} / \mathrm{g}$ in Mucuripe and 0.4 to $1.0 \mu \mathrm{g} / \mathrm{g}$ in Pecém. Values above $50 \mu \mathrm{g} / \mathrm{g}$ of these hydrocarbons can be related to polluted samples, while concentrations below $10 \mu \mathrm{g} / \mathrm{g}$ are normally from biogenic source and unpolluted sediments (Volkman et al. 1992). Based on these results, it can be suggested a natural input of these hydrocarbons for both areas.

Dominant hydrocarbons ranged from $n-\mathrm{C}_{17}$ to $n-\mathrm{C}_{31}$ in Mucuripe, while $n-\mathrm{C}_{29}$ and $n-\mathrm{C}_{31}$ predominated in sediment samples from Pecém. The alkanes $n-\mathrm{C}_{29}$ (M2, M3, M4, M6, P2, P4 and P5) and $n-\mathrm{C}_{31}$ (M7 and P1) were found in sediments with high $\%$ of fines and OM (depositional zones). In these sites, such molecules are related to inputs from terrestrial higher plants, as they are commonly found in environments situated close to land due to the composition of epicular waxes from leaves of mangrove trees (Shaw and Johns 1985). The metropolitan region of Fortaleza has $14.1 \mathrm{~km}^{2}$ of mangrove area with $60 \%$ distributed in urban zones (Cavalcante et al. 2009). Considering the direction of currents of sediment transport, the outflows from Pacoti and Cocó rivers are located upstream of the Mucuripe harbor, while Pecém is located downstream of both rivers, and also to Ceará river (Fig. 1), which explains the distribution of these compounds.

Moreover, $n$-alkanes with low molecular weight, such as $n-\mathrm{C}_{17}$, are related to phytoplankton origin, also indicating a biogenic source from marine primary production in M5, M8 and M10 (Requejo and Quinn 1983; Volkman et al. 1992).

Carbon preference index (CPI) is used to characterize the contribution of terrestrial plant waxes that have high CPI value ( $>3$ ) (NRC NRC, National Research Council 1985), and petroleum contribution that has CPI generally values around 1.0 (Wang et al. 1999). In this study, samples from most stations (except M9 an M10) presented values above 1.2, and sediments from M3, M5, M6 and M7 presented CPI values higher than 4, corroborating a biogenic contribution to the sediments.

The UCM can be defined as a raised baseline hump that is often observed in gas chromatograms of petroleum, which are related to the majority of molecules present in the total AHs that cannot be resolved by capillary GC columns (Volkman et al. 1992). The UCM is also a common feature in chromatograms of biodegraded oils and its presence can be used as an indicator of oil pollution (Frysinger et al. 2003). Even with low concentration, some samples presented signs of petroleum residues. The contents of UCM ranged from 80 to $85 \%$ of total hydrocarbons in the samples with near the effluent discharge from oil refinery in Mucuripe (M1-M4 and M7) and the sheltered sites of Pecém (P1-P3). Both these areas are shadowed by their respective jetties, which decreases the material-carrying capacity of waves and currents and therefore, the dispersion of compounds in the water column.

Total concentrations and diagnostic ratios for the identification of PAH origins are presented in Table 1. In sediments from Mucuripe and Pecém, total respective PAH levels ranged from 36.7 to $107 \mathrm{ng} / \mathrm{g}$ and from 31.9 to $292 \mathrm{ng} / \mathrm{g}$. These concentrations are low and presented a similar distribution to that found for AHs, with higher levels in sediments from sheltered zones of both areas, associated with fines sediments and organic matter.

The main sources of PAHs to the environment are anthropogenic and related to direct input of oil effluents or the incomplete combustion of fossil fuels (Readman et al. 2002). The main approaches for discrimination these sources includes the use of molecular markers and PAH diagnostic ratios (Tobiszewski and Namieśnik 2012). Aiming to identify the origin of $\mathrm{PAH}$, the following diagnostic ratios were calculated and the values indicate their respective sources: (1) $\sum \mathrm{LMW} / \sum \mathrm{HMW}<1$ pyrogenic source and $>1$ petrogenic source (Zhang et al. 2008); (2) $\mathrm{IP} /(\mathrm{IP}+\mathrm{BghiP})<0.2$ indicate dominance of petrogenic, $0.2-0.5$ petroleum combustion and $>0.5$ grass, wood and coal combustion (Yunker et al. 2002); and (3) BaA/ $(\mathrm{BaA}+\mathrm{Chry})<0.2$ petrogenic, $0.2-0.35$ coal combustion and $>0.35$ combustion (Yunker et al. 2002).

Hydrocarbons of low molecular weight (LMW) includes petrogenic hydrocarbons with 2 and 3 rings originated from non-combusted or low-temperature combusted PAHs, such as crude oil and refined products, whereas the hydrocarbons with high molecular weight (HMW) represents pyrogenic compounds with 4, 5 and 6 rings that are derived from combustion sources, such as vehicle exhaust, coal and forest fires (Bai et al. 2014; Ünlü et al. 2010). The ratios of $\sum \mathrm{LMW} / \sum \mathrm{HMW}$ varied from 0.1 to 0.6 in Mucuripe and from 0.3 to 0.6 in Pecém (Table 1), and these results suggest the contribution of pyrogenic processes to PAHs in sediments from both areas.

The cross plots of the ratios IP/(IP + BghiP) versus $\mathrm{BaA} /(\mathrm{BaA}+\mathrm{Chry})$ (Fig. 2) indicated that the sediments of sheltered areas in Mucuripe and Pecém are affected by PAH from oil combustion which typically occurs in harbor areas, originated by the traffic of fishing boats, commercial and industrial ships. Such emissions are associated with regions under influence of diffuse sources including not only harbor, but also industrial activities, combustion of fuel from motor vehicles, atmospheric inputs and urban runoff (Liu et al. 2005).

According to Cavalcante et al. (2012), the metropolitan region of Fortaleza has a considerable 


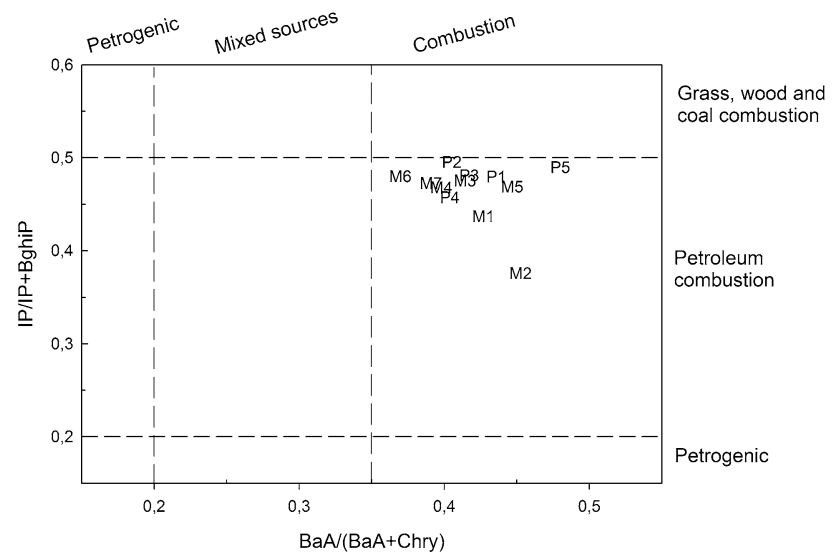

Fig. 2 PAH cross plots for the ratios: IP/(IP + BghiP) versus BaA/ $(\mathrm{BaA}+$ Chry $)$ for the sediments collected in Mucuripe and Pecém harbors. IP indeno[1,2,3-c,d]pyrene, BghiP benzo(ghi)perylene, $B a A$ benzo[a]anthracene, Chry chrysene

volume of vehicular emissions of PAHs, but still lower than those found in industrial and urban areas of developed countries. Moreover, the author pointed that the region is also surrounded by two industrial areas, a refinery at the northeast, located in the Mucuripe Harbor area, and other industries in the southwest, in the Maracanaú city. These data are in agreement with the study of Cavalcante et al. (2009), which also identified pyrogenic processes among the main sources of PAHs in sediments from the mangroves in Fortaleza, and stated that these PAHs are introduced in the aquatic environment by atmospheric deposition combined with the stormwater drain system.

In order to observe associations between the hydrocarbon distribution and sediment characteristics, Spearman's correlation coefficients were calculated assuming that the data do not present a Gaussian distribution. The results showed significant correlations $(p<0.05)$ for the fine sediments with $\mathrm{AHs}$ and also for all hydrocarbons with calcium carbonates and organic matter (Table 2). Hydrocarbons are compounds known for their ability to adsorb on organic or inorganic particles and precipitate onto the superficial sediments surface (Chiou et al. 1998). The data suggest that the depositional zones created by jetties in the sheltered areas of both harbors promote the sedimentation of fines particles and organic matter, including biogenic carbonates, controlling thus the occurrence and distribution of these compounds.
Table 2 Matrix of Spearman's correlation coefficients for hydrocarbons and characteristics of sediments from Mucuripe and Pecém harbors

\begin{tabular}{|c|c|c|c|c|c|c|c|c|}
\hline & Depth & Fines & $\mathrm{CaCO}_{3}$ & $\mathrm{OM}$ & TOC & Total LABs & Total AHs & Total PAH \\
\hline \multicolumn{9}{|l|}{ Depth } \\
\hline Coefficient & 1.00 & - & - & - & - & - & - & - \\
\hline$p$ value & - & - & - & - & - & - & - & - \\
\hline \multicolumn{9}{|l|}{ Fines } \\
\hline Coefficient & 0.03 & 1.00 & - & - & - & - & - & - \\
\hline$p$ value & 0.92 & - & - & - & - & - & - & - \\
\hline \multicolumn{9}{|l|}{$\mathrm{CaCO}_{3}$} \\
\hline Coefficient & 0.68 & 0.41 & 1.00 & - & - & - & - & - \\
\hline$p$ value & 0.01 & 0.13 & - & - & - & - & - & - \\
\hline \multicolumn{9}{|l|}{$\mathrm{OM}$} \\
\hline Coefficient & 0.50 & 0.29 & 0.88 & 1.00 & - & - & - & - \\
\hline$p$ value & 0.06 & 0.29 & 0.00 & - & - & - & - & - \\
\hline \multicolumn{9}{|l|}{ TOC } \\
\hline Coefficient & 0.53 & 0.46 & 0.91 & 0.93 & 1.00 & - & - & - \\
\hline$p$ value & 0.04 & 0.08 & 0.00 & 0.00 & - & - & - & - \\
\hline \multicolumn{9}{|l|}{ Total LABs } \\
\hline Coefficient & 0.48 & 0.28 & 0.70 & 0.78 & 0.67 & 1.00 & - & - \\
\hline$p$ value & 0.07 & 0.31 & 0.00 & 0.00 & 0.01 & - & - & - \\
\hline \multicolumn{9}{|l|}{ Total AHs } \\
\hline Coefficient & 0.08 & 0.51 & 0.60 & 0.70 & 0.77 & 0.47 & 1.00 & - \\
\hline$p$ value & 0.77 & 0.04 & 0.02 & 0.00 & 0.00 & 0.08 & - & - \\
\hline \multicolumn{9}{|l|}{ Total PAH } \\
\hline Coefficient & 0.45 & 0.11 & 0.67 & 0.45 & 0.48 & 0.39 & 0.46 & 1.00 \\
\hline$p$ value & 0.09 & 0.71 & 0.01 & 0.09 & 0.07 & 0.15 & 0.08 & - \\
\hline
\end{tabular}

Significant correlations are marked in bold 
Table 3 Compilation of hydrocarbons in marine and coastal sediments from northeast, southeast and South of Brazil and Sediment Quality Guidelines

\begin{tabular}{|c|c|c|c|c|c|c|c|c|}
\hline Location & State & Samples & $\%$ Mud & $\%$ TOC & $\begin{array}{l}\text { Total LABs } \\
(\mathrm{ng} / \mathrm{g})\end{array}$ & $\begin{array}{l}\text { Total AHs } \\
(\mu \mathrm{g} / \mathrm{g})\end{array}$ & $\begin{array}{l}\text { Total PAH } \\
(\mathrm{ng} / \mathrm{g})\end{array}$ & Author \\
\hline \multicolumn{9}{|l|}{ Northeast } \\
\hline $\begin{array}{l}\text { Todos os Santos } \\
\text { bay }\end{array}$ & Bahia & 30 sites & 0-99 & $0.1-5.4$ & - & - & $42-4187$ & A \\
\hline $\begin{array}{l}\text { Mundaú- } \\
\text { Manguaba }\end{array}$ & Alagoas & $\begin{array}{l}4 \text { cores and } 46 \\
\text { samples }\end{array}$ & - & $1.9-3.3$ & - & 29-139 & $29-223$ & B \\
\hline Potiguar basin & $\begin{array}{l}\text { Rio Grande do } \\
\text { Norte }\end{array}$ & 26 sites & - & $0.6-0.8$ & - & $0.1-5$ & $0.5-10$ & $\mathrm{C}$ \\
\hline $\begin{array}{l}\text { Estuary of Ceará } \\
\text { river }\end{array}$ & Ceará & $\begin{array}{l}3 \text { cores/sites and } 19 \\
\text { samples }\end{array}$ & - & $0.01-1$ & - & - & $3-2235$ & $\mathrm{D}$ \\
\hline $\begin{array}{l}\text { Estuary of Cocó } \\
\text { river }\end{array}$ & Ceará & $\begin{array}{l}3 \text { cores/sites and } 26 \\
\text { samples }\end{array}$ & - & $0.01-1.6$ & - & - & $3-1859$ & $\mathrm{D}$ \\
\hline Mucuripe harbor & Ceará & 10 sites & $0.1-24.4$ & $0.2-1.4$ & $1.3-5.8$ & $0.3-25$ & $28-108$ & $\mathrm{E}$ \\
\hline Pecém harbor & Ceará & 5 sites & $4.4-14.3$ & $0.5-1.4$ & $1.6-4$ & $1-19$ & $31-292$ & $\mathrm{E}$ \\
\hline \multicolumn{9}{|l|}{ Southeast and South } \\
\hline Patos lagoon & $\begin{array}{l}\text { Rio Grande do } \\
\text { Sul }\end{array}$ & 10 sites & - & - & $3-1602$ & $1-129$ & $38-11,780$ & $\mathrm{~F}$ \\
\hline Guaratuba bay & Paraná & $\begin{array}{l}2 \text { cores/sites and } 43 \\
\text { samples }\end{array}$ & - & - & - & - & $10-349$ & G \\
\hline Laranjeiras bay & Paraná & 10 sites & - & - & - & $0.3-8.2$ & $4-89$ & $\mathrm{H}$ \\
\hline $\begin{array}{l}\text { Santos estuarine } \\
\text { system }\end{array}$ & São Paulo & 26 sites & $0.3-81$ & - & $16-430$ & $0.2-2508$ & $22-68,130$ & $\mathrm{I}, \mathrm{J}$ \\
\hline São Sebastião & São Paulo & 47 sites & $0.2-100$ & - & $13-28$ & $0.1-8.53$ & $3-370$ & $\mathrm{~K}, \mathrm{~L}$ \\
\hline Guanabara Bay & Rio de Janeiro & 35 sites & - & $0.04-12$ & - & $0.8-21,260.4$ & $96-153,316$ & M \\
\hline \multicolumn{6}{|c|}{ Sediment Quality guidelines (SQGs) } & - & $4000^{\mathrm{b}}$ & $\mathrm{N}$ \\
\hline \multicolumn{6}{|c|}{ Site specific SQGs for Santos } & - & $163^{\mathrm{a}}-950^{\mathrm{b}}$ & $\mathrm{O}$ \\
\hline
\end{tabular}

$A$ Wagener et al. (2010), $B$ Silva et al. (2013), $C$ Wagener et al. (2011), D Cavalcante et al. (2009), $E$ This study, $F$ Medeiros et al. (2005), $G$ Pietzsch et al. (2010), $H$ Martins et al. (2012), I Medeiros and Bícego (2004a), J Bícego et al. (2006), $K$ Medeiros and Bícego (2004b), L Silva and Bícego (2010), $M$ Wagener et al. (2012), $N$ Brasil (2012), $O$ Choueri et al. (2009)

a Threshold effects level

b Probable effects level

A brief compilation of recent available data on hydrocarbon concentrations in coastal regions of Northeast (Tropical), Southeast and South (Subtropical) of the Brazilian coast is presented in Table 3. As mentioned before, the concentrations found in the northeast areas are lower than those found in industrialized areas such as Patos lagoon, Santos estuarine system, São Sebastião channel, Guanabara bay and Todos os Santos bay.

By comparing both harbors, levels of AHs and LABs were similar, and for PAHs the concentrations found in Pecém were higher than Mucuripe. The LABs concentrations were similar to those found in São Sebastião channel, a region with higher hydrodynamics (Medeiros and Bícego 2004b) and where the São Sebastião port and an oil terminal are installed. Also, these concentrations may indicate a low impact of sewage effluents.
Levels of AHs and PAHs reported in the present study were similar to those reported for Mundaú-Manguaba, a low-impacted estuarine lagoon system (Silva et al. 2013), and high compared to levels of Potiguar basin, which were considered as reference levels for monitoring of shore oil exploration that occurs in the northeast coast (Wagener et al. 2011).

The occurrence of hydrocarbons in the environment especially in sediments may result in negative effects on aquatic organisms. For example, molecular weight of PAHs ranging from 128 to $300 \mathrm{~g} / \mathrm{mol}$ (naphthalene to coronene, respectively) and such group of compounds tend to be more soluble, which increases their potential bioavailability and mobility within the environmental compartments (Arfsten et al. 1996) an thus, their toxicity. Regarding detergents, data available are related to the toxicity of LAS and since the concentrations of LABs are used as a marker of LAS, the 
relationship between levels of LABs and their potential toxicity may not be easily estimated.

It is commonly accepted that AHs have a lower toxicity potential than PAHs, but they have received special attention because they are the major chemical class in modern oil-base drilling muds (Payne et al. 1995). These authors also investigated chronic effects of AH-rich sediments on winter flounder Pleuronectes americanus. Such effest involved the analysis of organ and body condition indices, energy reserves, detoxification enzymes, blood parameters, and histopathology and they found no effects or dose-response relationships at exposure levels similar to those found in our study $(6-21 \mu \mathrm{g} / \mathrm{g}$ of AHs). Howerver, Thomas et al. (1995) pointed that an oxidation of AHs resulted in the formation of products with a greater solubility, and increased in two times the toxic effects on the feeding rate of mussel Mytilus edulis.

As mentioned, PAHs are toxic and some of these compounds are mutagenic and genotoxic, threatening thus the marine biota through chronic exposure (Oros et al. 2007). The toxicological concerns of PAHs are focused on metabolic activation of these compounds to metabolites more toxic than their parent compound (Mekenyan et al. 1994) and one well know process that act in such activation is the exposure of UV radiation. Arfsten et al. (1996) presented a review containing evidences that PAHs may become toxic or substantially more toxic upon coexposure to UV light. According to Nikolaou et al. (2009) toxic effects from some individual PAHs are documented, but in the presence of complex mixtures (e.g., superficial sediments) dose-response relationship for PAHs is difficult to identify.

Considering the potential toxicity of these substances, a chemical-specific criterion was applied by comparing the concentrations of PAHs with SQGs. Comparison with Brazilian SQGs revealed that the highest concentrations of total PAH found in Mucuripe and Pecém sediments were lower than probable effects level. However, when these concentrations were compared with site-specific values developed for Santos Estuarine System (Choueri et al. 2009), where the major Brazilian port is situated, the upper levels observed in Pecém (P2 and P5) were already higher than the threshold effect level. These results suggest that even the exposure of benthic organisms to low concentrations of contaminants may be associated with toxic effects. Thus, based on these results further investigations should be carried out in order to assess the potential of toxicity of the sediments in Northeastern coast of Brazil, especially in harbor areas.

\section{Conclusions}

In general, hydrocarbon levels in sediments from some tropical areas of Brazil were low when compared with other industrialized areas. Analysis of $n$-alkanes revealed the input of biogenic compounds and according to diagnostic ratios, PAHs in both harbors originated from fuel combustion, possibly from shipping. PAH concentrations were low and below threshold levels established by the SQGs. Data presented in this study can also assist the monitoring of harbor areas and the management of dredged material by providing information on two of the main ports of northeast region of Brazil, which lacks of data on sediment quality, especially regarding the distribution of hydrocarbons.

Acknowledgments This research was supported by the port authorities of the Ceará state (DOCAS DO CEARÁ and CEARÁPORTOS) and sponsored by FUNCAP (Foundation for Research Support of Ceará state) and CNPQ (Brazilian National Research Council). LM Buruaem (Ph.D. Grant 142002/2010-0) and DMS. Abessa (552299/2010-3) were sponsored by CNPq.

\section{References}

Arfsten DP, Schaeffer DJ, Mulveny DC (1996) The effects of near ultraviolet radiation on the toxic effects of polycyclic aromatic hydrocarbons in animals and plants: a review. Ecotoxicol Environ Saf 33(1):1-24

Bai Y, Meng W, Xu J, Zhang Y, Guo C, Lv J, Wan J (2014) Occurrence, distribution, environmental risk assessment and source apportionment of polycyclic aromatic hydrocarbons (PAHs) in water and sediments of the Liaohe river basin, China. Bull Environ Contam Toxicol 93(6):744-751

Bícego MC, Taniguchi S, Yogui GT, Montone RC, Silva DAM, Lourenço RA, Martins CC, Sasaki ST, Pellizari VH, Weber RR (2006) Assessment of contamination by polychlorinated biphenyls and aliphatic and aromatic hydrocarbons in sediments of the Santos and São Vicente estuary system, São Paulo, Brazil. Mar Pollut Bull 52(12):1784-1832

Brasil (2012) Estabelece as diretrizes gerais e os procedimentos referenciais para o gerenciamento do material a ser dragado em águas sob jurisdição nacional. Diário Oficial, Brasília, Edição ${ }^{\circ}$ 216 de 08/11/2012. Resolution no 454, dated 11/01/2012

Burton GA Jr (2002) Sediment quality criteria in use around the world. Limnology 3(2):65-75

Buruaem LM, Hortellani MA, Sarkis JE, Costa-Lotufo LV, Abessa DMS (2012) Contamination by metals of port zones sediments from large marine ecosystems of Brazil. Mar Pollut Bull 64(3):479-488

Cavalcante RM, Sousa FW, Nascimento RF, Silveira ER, Freire GSS (2009) The impact of urbanization on tropical mangroves (Fortaleza, Brazil): evidence from PAH distribution in sediments. J Environ Manage 91(2):328-335

Cavalcante RM, Andrade MVF, Marins R V, Oliveira LDM (2010) Development of a headspace-gas chromatography (HS-GC-PIDFID) method for the determination of VOCs in environmental aqueous matrices: optimization, verification and elimination of matrix effect and VOC distribution on the Fortaleza Coast, Brazil. Microchem J 96:337-343

Cavalcante RM, Sousa FW, Nascimento RF, Silveira ER, Viana RB (2012) Influence of urban activities on polycyclic aromatic hydrocarbons in precipitation: distribution, sources and depositional flux in a developing metropolis, Fortaleza, Brazil. Sci Total Environ 414:287-292

Chiou CT, McGroddy SE, Kile DE (1998) Partition characteristics of polycyclic aromatic hydrocarbons on soils and sediments. Environ Sci Technol 32(2):264-269 
Choueri RB, Cesar A, Abessa DMS, Torres RJ, Morais RD, Riba I, Pereira CDS, Nascimento M, Mozeto AA, DelValls AT (2009) Development of site-specific sediment quality guidelines for North and South Atlantic littoral zones: comparison against national and international sediment quality benchmarks. J Hazard Mater 170(1):320-331

Eganhouse RP (1986) Long-chain alkylbenzenes: their analytical chemistry, environmental occurrence and fate. Int J Environ Anal Chem 26(3-4):241-263

Freire GSS, Lima S, Maia LP, Lacerda LD (2004) Geochemistry of continental shelf sediments of the Ceará coast, NE Brazil. In: Lacerda LD, Santelli RE, Duursma EK, Abrão JJ (eds) Facets of environmental geochemistry in tropical and subtropical environments. Springer Verlag, Berlin, pp 365-378

Frysinger GS, Gaines RB, Xu L, Reddy CM (2003) Resolving the unresolved complex mixture in petroleum-contaminated sediments. Environ Sci Technol 37(8):1653-1662

Gross MG (1971) Carbon determination. In: Carver RE (ed) Procedures in sedimentary petrology. Wiley-Interscience, New York, pp 573-596

Lacerda LD, Marins RV (2005) Geoquímica de sedimentos e o monitoramento de metais na plataforma continental nordeste oriental do brasil. Geochim Bras 20:123-135

Liu GQ, Zhang G, Li XD, Li J, Peng XZ, Qi SH (2005) Sedimentary record of polycyclic aromatic hydrocarbons in a sediment core from the Pearl river estuary, South China. Mar Pollut Bull 51(8-12):912-921

Loring DH, Rantala RTT (1992) Manual for the geochemical analyses of marine sediments and suspended particulate matter. Earth-Sci Rev 32:235-283

Luczak C, Janquin M, Kupka A (1997) A simple standard procedure for the routine determination of organic matter in marine sediment. Hydrobiologia 345(1):87-94

Maia LP, Jimenez JA, Serra J, Morais JO (1998) The coastline of Fortaleza City. A product of environmental impacts caused by the Mucuripe Harbor. Arq Cienc (1-2): 93-100

Martins CC, Bícego MC, Figueira RCL, Angelli JLF, Combi T, Gallice WC, Mansur AV, Nardes E, Rocha ML, Wisnieski E, Ceschim LMM, Ribeiro AP (2012) Multi-molecular markers and metals as tracers of organic matter inputs and contamination status from an environmental protection area in the SW Atlantic (Laranjeiras bay, Brazil). Sci Total Environ 417-418:158-168

Medeiros PM, Bícego MC (2004a) Investigation of natural and anthropogenic hydrocarbon inputs in sediments using geochemical markers. I. Santos, SP-Brazil. Mar Pollut Bull 49(9-10):761-769

Medeiros PM, Bícego MC (2004b) Investigation of natural and anthropogenic hydrocarbon inputs in sediments using geochemical markers. II. São Sebastião, SP-Brazil. Mar Pollut Bull 49(11-12):892-899

Medeiros PM, Bícego MC, Castelão RM, Rosso CD, Filmann G, Zamboni AJ (2005) Natural and anthropogenic hydrocarbon inputs to sediments of Patos lagoon estuary, Brazil. Environ Int 31(1):77-87

Mekenyan OG, Ankley GT, Veith GD, Call DJ (1994) QSARs for phototoxicity. I. Acute lethality of polycyclic aromatic hydrocarbons to Daphnia magna. Chemosphere 28(3):567-582

Mudroch A, Macknight SD (1994) Handbook of techniques for aquatic sediments sampling, 2nd edn. CRC, Boca Raton 236p

Nikolaou A, Kostopoulou M, Lofrano G, Meric S, Petsas A, Vagi M (2009) Levels and toxicity of polycyclic aromatic hydrocarbons in marine sediments. Trac Trend Anal Chem 28(6):653-664

NRC, National Research Council (1985) Oil in the sea, inputs, fates and effects. National Academy Press, Washington 602p

NRC, National Research Council (1997) Contaminated sediments in ports and waterways: cleanup strategies and technologies.
Commission on engineering and technical systems. National Research Council, Washington, p 320p

Oros DR, Ross JRM, Spies RB, Mumley T (2007) Polycyclic aromatic hydrocarbon (PAH) contamination in San Francisco bay: a 10-year retrospective of monitoring in an urbanized estuary. Environ Res 105(1):101-118

Payne JF, Fancey LL, Hellou J, King MJ, Fletcher GL (1995) Aliphatic hydrocarbons in sediments: a chronic toxicity study with winter flounder Pleuronectes americanus exposed to oil we1 cuttings. Can J Fish Aquat Sci Vsl 52:1995

Pietzsch R, Patchineelam SR, Torres JPM (2010) Polycyclic aromatic hydrocarbons in recent sediments from a subtropical estuary in Brazil. Mar Chem 118:56-66

Raymundo CC, Preston MR (1992) The distribution of linear alkylbenzenes in coastal and estuarine sediments of the western North sea. Mar Pollut Bull 24(3):138-146

Readman JW, Fillmann G, Tolosa I, Bartocci J, Villeneuve JP, Catinni C, Mee LD (2002) Petroleum and PAH contamination of the Black sea. Mar Pollut Bull 44(1):48-62

Requejo AG, Quinn JG (1983) Formation of $n$-alkenes during anaerobic decomposition of a marine algal mat. Nature 305:520-523

Shaw PM, Johns RB (1985) Organic geochemical studies of a recent inner great barrier reef sediment-I. Assessment of input sources. Org Geochem 8(2):147-156

Sherblom PM, Gschwend PM, Eganhouse RP (1992) Aqueous solubility, vapor pressure, and $n$-octanol-water partition coefficients for $\mathrm{C}_{9}-\mathrm{C}_{14}$ linear alkylbenzenes. $\mathrm{J}$ Chem Eng Data 37(4):394-399

Silva DAM, Bícego MC (2010) Polycyclic aromatic hydrocarbons and petroleum biomarkers in São Sebastião channel, Brazil: assessment of petroleum contamination. Mar Environ Res 69(5):277-286

Silva TR, Lopes SRP, Spörl G, Knoppers BA, Azevedo DA (2013) Evaluation of anthropogenic inputs of hydrocarbons in sediment cores from a tropical Brazilian estuarine system. Microchemistry J 109:178-188

Thomas KV, Donkin P, Rowland SJ (1995) Toxicity enhancement of an aliphatic petrogenic unresolved complex mixture (UCM) by chemical oxidation. Wat Res 29(1):379-382

Tobiszewski M, Namieśnik J (2012) PAH diagnostic ratios for the identification of pollution emission sources. Environ Pollut 162:110-119

UNEP United Nations Environment Programme (1992) Determinations of petroleum hydrocarbons in sediments. Reference methods for marine pollution studies $20 \mathbf{7 5 p}$

Ünlü S, Alpar B, Öztürk K, Vardar D (2010) Polycyclic aromatic hydrocarbons (PAHs) in the surficial sediments from lake Iznik (Turkey): spatial distributions and sources. Bull Environ Contam Toxicol 85(6):573-580

USEPA United States Environmental Protection Agency (2003) Procedures for the derivation of equilibrium partitioning sediment benchmarks (ESBs) for the protection of benthic organisms: PAH mixtures. Washington. EPA/600/R-02/013

Volkman JK, Holdworth DG, Neill GP, Bavor HJ Jr (1992) Identification of natural, anthropogenic and petroleum hydrocarbons in aquatic sediments. Sci Total Environ 112:203-219

Wagener A, Hamacher C, Farias C, Godoy JM, Scofield A (2010) Evaluation of tools to identify hydrocarbon sources in recent and historical sediments of a tropical bay. Mar Chem 121(1-4):67-79

Wagener ALR, Carreira RS, Hamacher C, Scofield AL, Farias CO, Cordeiro LGMS, Luz LG, Baêta AP, Kalas FA (2011) Hydrocarbon composition and distribution in a coastal region under influence of oil production in northeast Brazil. Mar Pollut Bull 62(8):1877-1882 
Wagener ALR, Meniconi MFG, Hamacher C, Farias CO, Silva GC, Gabardo IT, Scofield AL (2012) Hydrocarbons in sediments of a chronically contaminated bay: the challenge of source assignment. Mar Pollut Bull 64(2):284-294

Wang Z, Fingas M, Page D (1999) Oil spill identification. J Chromatogr A 843(1-2):369-411

Wei G, Liu L, Bao L, Zeng EY (2014) Tracking anthropogenic influences on the continental shelf of China with sedimentary linear alkylbenzenes (LABs). Mar Pollut Bull 80(1-2):80-87
Yunker MB, Macdonald RW, Vingarzan R, Mitchell RH, Goyette D, Sylvestre S (2002) PAHs in the Fraser river basin: a critical appraisal of PAH ratios as indicators of PAH source and composition. Org Geochem 33(4):489-515

Zhang W, Zhang S, Wan C, Yue D, Ye Y, Wang X (2008) Source diagnostics of polycyclic aromatic hydrocarbons in urban road runoff, dust, rain and canopy throughfall. Environ Pollut 153(3):594-601 